\title{
Analisis Kebutuhan Pengembangan Kolaborasi Metode Pembelajaran Bahasa
}

\author{
Tri Budianingsih ${ }^{1}$, Nanda Lailatul Qadriani ${ }^{1}$ \\ ${ }^{1}$ Program studi Bahasa Mandarin dan Kebudayaan Tiongkok, Fakultas Ilmu Pengetahuan Budaya, \\ Universitas Al Azhar Indonesia, Masjid Agung Al-Azhar, Jl. Sisingamangaraja, Kota Jakarta Selatan, 12110 \\ Penulis untuk Korespondensi/E-mail: trixiaodi@gmail.com
}

\begin{abstract}
This study aims to determine whether new learning methods are needed by students in learning Mandarin, as well as to find out what methods they need so that these methods are right on target. This research uses a descriptive method. The research subjects were lecturers and students of level 2 (two) semester 3 (three) in the Mandarin written skills course, totaling 30 students. The data collection technique is a direct technique and the data used is a questionnaire. The data were analyzed with a simple calculation, namely the average. The total achievement from the needs analysis of the 9 components is 3.89, greater than the expected achievement of 3.00, if sorted from the highest total achievement is (1) the criteria component for reflex activity needs, (2) the criteria for the need for closing activities, (3) the criteria component core activity needs, (4) component of theme criteria, (5) component of approach criteria, (6) component of learning criteria, (7) component of initial activity criteria, (8) component of RPS needs identification criteria and, (9) component of learning objective criteria. Thus it can be concluded that students also need new learning methods so that the material presented is conveyed well, the method needed by students is a combination of peer tutoring and quantum teaching.
\end{abstract}

Abstrak - Penelitian ini bertujuan untuk mengetahui apakah metode pembelajaran yang baru dibutuhkan oleh mahasiswa dalam mempelajari bahasa Mandarin, juga mengetahui metode yang bagaimana mereka butuhkan agar metode tersebut tepat sasaran. Penelitian ini menggunakan metode deskriptif. Subjek penelitian yaitu dosen dan mahasiswa tingkat 2 (dua) semester 3 (tiga) pada mata kuliah keterampilan tertulis bahasa Mandarin yang berjumlah 30 mahasiswa. Teknik pengumpulan data adalah Teknik langsung dan data yang digunakan adalah kusioner. Data tersebut dianalisis dengan perhitungan sederhana yaitu rata-rata. Total pencapaian dari analisis kebutuhan dari 9 komponen sebesar 3.89, lebih besar dari pencapaian yang diharapkan yaitu sebesar 3.00, jika diurutkan dari otal pencapaian tertinggi adalah (1) Komponen kriteria kebutuhan kegiatan refreksi, (2) Kriteria kebutuhan kegiatan penutup, (3) Komponen kriteria kebutuhan kegiatan inti, (4) Komponen kriteria tema, (5) Komponen kriteria pendekatan, (6) Komponen kriteria pembelajaran, (7) Komponen kriteria kegiatan awal, (8) Komponen kriteria identifikasi kebutuhan RPS dan, (9) Komponen kriteria tujuan pembelajaran. Dengan demikian dapat disimpulkan mahasiswa juga membutuhkan metode pembelajaran yang baru agar materi yang disampaikan tersampaikan dengan baik, metode yang dibutuhkan oleh mahasiswa adalah metode gabungan tutor teman sebaya dengan quantum teaching.

Keywords - Quantum Teaching, Peer Tutor, Mandarin. 


\section{PENDAHULUAN}

$\mathrm{P}$ engembangan metode pembelajaran dibutuhkan untuk perkembangan dan kualitas peningkatan pendidikan yang lebih baik. Pembelajaran merupakan perpaduan antara kegiatan pengajaran yang dilakukan guru dan kegiatan belajar yang dilakukan oleh siswa. Dalam kegiatan pembelajaran tersebut, terjadi interaksi antara siswa dengan siswa, interaksi antara guru dan siswa, maupun interaksi antara siswa dengan sumber belajar. Diharapkan dengan adanya interaksi tersebut, siswa dapat membangun pengetahuan secara aktif, pembelajaran berlangsung secara interaktif, menyenangkan, menantang, serta dapat memotivasi peserta didik sehingga mencapai kompetensi yang diharapkan. [1], sedangkan [2] mengatakan penelitian dan pengembangan adalah suatu proses atau langkahlangkah untuk mengembangkan suatu produk baru atau menyempurnakan produk yang telah ada, yang dapat dipertanggung jawabkan. Produk tersebut tidak selalu berbentuk benda atau perangkat keras, seperti buku, modul, alat bantu pembelajaran di kelas atau di laboratorium, tetapi bisa juga perangkat lunak, seperti program komputer untuk pengolahan data, metode pembelajaran di kelas, perpustakaan atau laboratorium, ataupun model-model pendidikan, pembelajaran, pelatihan, bimbingan, evaluasi, manajemen dan lain-lain.

Metode quantum teaching merupakan metode pembelajaran yang berorientasi pada peserta didik student centered dan lebih memfokuskan interaksi siswa dengan teman-temannya sehingga dapat menciptakan pembelajaran yang menyenangkan. Metode quantum teaching memiliki kerangka rencana (langkah-langkah) pembelajaran yang disebut TANDUR (Tumbuhkan, Alami, Namai, Demonstrasi, Ulangi, dan Rayakan) sehingga penamaan metode pembelajaran Ziran diambil dari langkah metode quantum teaching yang diterjemahkan ke dalam bahasa Mandarin yaitu Alami (Ziran 自然). Hal ini sangat sejalan dengan metode tutor teman sebaya yaitu juga berorientasi pada siswa, memfokuskan pada interaksi siswa dengan temannya karena pada 5 (lima) tahapan metode tutor teman sebaya ada pembentukan kelompok, penyampaian materi oleh tutor, diskusi kelompok, presentasi kelas dan klarifikasi. Sehingga metode quantum teaching dapat berkolaborasi dengan metode tutor teman sebaya karena memiliki tujuan dan tahapan proses pembelajaran yang sama.
Penelitian-penelitian yang telah dilakukan sudah terbukti dapat meningkatkan hasil belajar siswa, seperti penelitian yang dilakukan oleh Niken dalam penerapan model tutor sebaya pada mata pelajaran bahasa Inggris Reported Speech menunjukkan bahwa peningkatan yang signifikan pada hasil belajar siswa yaitu dengan nilai rata-rata (mean) sebesar 79,23 dan nilai tengah (median) sebesar 80,0, sedangkan simpangan baku (standart deviation) sebesar 10,141 menunjukkan peningkatan diatas nilai KKM 75. Selain itu pada hasil penelitian juga terlihat bahwa pelaksanaan dalam penerapan model pembelajaran ini berjalan dengan baik sesuai dengan sintak pembelajaran yang direncanakan, tutor sebaya juga melakukan tugasnya sebagai pembimbing temannya dengan baik. Selain model tutor sebaya, model quantum teaching juga telah terbukti dalam meningkatkan hasil belajar siswa, salah satu penelitian tentang quantum teaching yaitu Pengaruh Pembelajaran Kuantum Berorientasi Pemecahan Masalah Dalam Pembelajaran Matematika Terhadap Penalaran Mahasiswa yang dilakukan oleh I Gusti Ngurah Japa, hasil yang didapat dalam penelitian tersebut yaitu dibandingkan dengan model pembelajaran konvensional, model pembelajaran kuantum berorientasi pemecahan masalah terbuka dalam pembelajaran matematika menghasilkan capaian yang lebih baik dalam keterampilan berpikir dasar, keterampilan berpikir kritis dan keterampilan berpikir kreatif mahasiswa. Sehingga model pembelajaran kuantum dapat meningkatkan hasil belajar siswa.

Penggabungan dua metode pembelajaran tutor teman sebaya dan quantum teaching seperti yang sudah dijelaskan sebelumnya sangat cocok dalam pembelajaran yang membuat siswa lebih aktif, kreatif, termotivasi dan dapat menyerap materi dengan baik, hal tersebut telah dibuktikan pada penelitian Rahayu yang berjudul Upaya Meningkatkan Pemahaman dan Minat Belajar Siswa Melalui Penggunaan Metode Quantum Teaching dan Tutor Sebaya, dalam hasil penelitiannya disimpulkan adanya perubahan dalam proses pembelajaran yaitu keaktifan siswa pada saat pembelajaran berlangsung, nilai skor tes akhir dari masing-masing siklus. Dalam penelitian ini Rahayu menggabungkan kedua metode tersebut bukan dari penggabungan langkah dari kedua metode tersebut, tapi pada metode quantum teaching yang diharapkan adalah manfaat dari tujuan metode tersebut membuat siswa merasa nyaman dalam belajar, 
suasana yang nyaman juga menyenangkan sehingga mampu meningkatkan pemahaman mereka terhadap suatu materi, sedangkan pada metode tutor sebaya menggunakan langkah-langkah. Sehingga berbeda dengan penelitian yang akan peneliti kembangkan saat ini.

Pengembangan metode pembelajaran yang akan dikembangkan adalah metode pembelajaran Ziran, metode pembelajaran ini merupakan penggabungan atau kolaborasi metode quantum teaching dengan tutor teman sebaya, dengan penggabungan langkahlangkah dari kedua metode tersebut. Permasalahan penelitian ini difokuskan pada satu permasalahan yaitu menganalisis kebutuhan mahasiswa dan dosen pengampuh mata kuliah keterampilan bahasa tertulis lanjutan A\&B, apakah metode pembelajaran Ziran dibutuhkan oleh mereka?, bagaimana kebutuhan mahasiswa dan dosen pengampuh mata kuliah keterampilan bahasa tertulis lanjutan $A \& B$ ?, dan menganalisis karakteristik mahasiswa, apakah cocok dengan gaya belajar mahasiswa mata kuliah keterampilan bahasa tertulis lanjutan $\mathrm{A} \& \mathrm{~B}$ ?

Tujuan penelitian ini adalah untuk menganalisis kebutuhan pengembangan metode pembelajaran Ziran berbasis tutor teman sebaya dalam pembelajaran bahasa Mandarin, kedepannya akan melahirkan sebuah metode pembelajaran yang baru hasil dari penggabungan metode pembelajaran quantum teaching dengan tutor teman sebaya. Berdasarkan latar belakang di atas peneliti membuat penelitian dengan judul "analisis kebutuhan pengembangan metode pembelajaran Ziran berbasis tutor teman sebaya dalam pembelajaran bahasa Mandarin."

Ruang lingkup penelitian ini lebih menekankan pada keterampilan menulis mahasiswa tingkat dua prodi bahasa Mandarin dan kebudayaan Tiongkok Universitas Al Azhar Indonesia. Urgensi Penelitian ini memberikan pandangan kepada mahasiswa dan dosen pentingnya kebutuhan dalam pengembangan metode pembelajaran yang baru yaitu metode Ziran untuk kemajuan pembelajaran dan dunia pendidikan. Perlu diketahui hasil pembelajaran dipengaruhi dua faktor yaitu metode pembelajaran yang digunakan pengajar dan minat serta usaha pembelajar itu sendiri. Penelitian ini diharapkan dapat menghasilkan metode pembelajaran yang baru sesuai dengan kebutuhan pembelajar.

Metode pembelajaran Ziran merupakan metode yang akan dikembangkan dengan menggabungkan metode quantum teaching, diskusi kelompok dan tutor teman sebaya. Adapun penggabungan metode tersebut yang paling banyak digunakan adalah tutor teman sebaya karena dalam metode ini siswa lebih sering berinteraksi dengan teman sebayanya baik di dalam kelas maupun di luar kelas. Tahapan dalam metode ini sebagian besar mengikuti tahapan tutor teman sebaya, penambahannya pada tahap setelah pembentukkan kelompok siswa terlebih dahulu mengALAMI (Ziran) sendiri materi yang diberikan dengan memilih gaya belajarnya, misalkan bagi siswa auditorial mendengarkan rekaman mengenai materi yang diberikan, begitupun juga bagi siswa dengan gaya belajar visual, audiovisual, dan kinestetik.

\section{Analisis Kebutuhan}

Analisis kebutuhan adalah usaha untuk mencari dan menggambarkan kebutuhan bahasa yang memiliki atau yang diinginkan oleh siswa dalam suatu program. Menurut Graves analisis kebutuhan merupakan kerja sistematis dan proses yang terus dilakukan untuk mengumpulkan informasi tentang kebutuhan siswa dan kecenderungannya, menginterpretasi, kemudian membuat materi ajar berdasarkan interpretasi tersebut agar mengenai sasaran. Analisis kebutuhan memiliki berbagai tujuan dalam pembelajaran bahasa, yaitu: 1) mengetahui kebutuhan tentang keterampilan berbahasa siswa sehingga dapat melaksanakan peran tertentu, misalnya manager pemasaran, pemandu wisata, dan mahasiswa, 2) membantu dalam menentukan ketepatan materi ajar terhadap kebutuhan siswa berpotensi, 3) memilih siswa dalam satu kelompok yang betul-betul memerlukan latihan keterampilan berbahasa tertentu, 4) mengenali kemungkinan peluang seseorang dalam kelompok merasa penting, 5) mengenali jarak antara apa yang mampu pelajar lakukan dan apa yang perlu mampu mereka lakukan, 6) mengumpulkan informasi tentang pengalaman permasalahan khusus siswa [3].

\section{Tutor Teman Sebaya}

Metode tutor teman sebaya merupakan salah satu metode pembelajaran yang berpusat pada siswa (student centered learning), dimana siswa dituntut untuk lebih aktif dan guru hanya sebagai fasilitator. Penerapan metode pembelajaran tutor teman sebaya (peer tutoring) dilaksanakan dalam 5 tahap, yaitu pembentukan kelompok, penyampaian materi oleh tutor, diskusi kelompok, presentasi kelas dan klarifikasi [4]. Metode tutor sebaya adalah suatu metode pembelajaran yang dilakukan dengan cara memberdayakan siswa yang memiliki daya serap yang tinggi dari kelompok siswa itu sendiri untuk menjadi tutor bagi teman- temannya, dimana siswa 
yang menjadi tutor bertugas untuk memberikan materi belajar dan latihan kepada teman-temannya (tutee) yang belum faham terhadap materi/ latihan yang diberikan guru dengan dilandasi aturan yang telah disepakati bersama dalam kelompok tersebut, sehingga akan terbangun suasana belajar kelompok yang bersifat kooperatif bukan kompetitif [5].

\section{Keterampilan Menulis}

$\mathrm{Wu}$ zhong wei mengatakan dalam empat keterampilan berbahasa yaitu mendengar, berbicara, membaca dan menulis, keterampilan menulis dianggap sebagai keterampilan berbahasa yang sangat sulit, dalam tes ujian kemampuan bahasa Mandarin, tes tertulis hanya muncul pada tingkat mahir [6]. Oleh karena itu, banyak mahasiswa merasakan bahwa keterampilan menulis merupakan keterampilan yang sangat sulit dan menakutkan. Ada banyak faktor yang mempengaruhi keterampilan menulis, yaitu menganalisa tujuan dan isi dari pengajaran menulis, mengintegrasikan permasalahan yang sering muncul dalam pengajaran menulis, membicarakan prinsip dalam pengajaran menulis, model pengajaran dan cara pengajaran.

Keterampilan menulis merupakan keterampilan yang sangat istimewa yang dimiliki manusia karena dapat menuangkan ide, sesuatu hal yang ingin diketahui dan yang disampaikan. Dalam pembelajaran kedua keterampilan menulis merupakan fitur bahasa yang lengkap juga komprehensif karena memiliki konten bahasa yang spesifik. Kemampuan bahasa seseorang akan terlihat pada keterampilan menulis karena akan terlihat pada isi konten, penggunaan kata dan tata bahasanya.

Keterampilan menulis merupakan salah satu aspek keterampilan berbahasa yang sangat penting dalam kehidupan manusia, seseorang dapat mengungkapkan ide, pikiran, perasaan kepada orang lain melalui tulisan. Keterampilan menulis menurut [7] keterampilan menulis merupakan salah satu jenis keterampilan berbahasa menulis yang bersifat produktif, artinya keterampilan ini merupakan keterampilan yang menghasilkan, dalam hal ini menghasilkan tulisan. [8] mengemukakan bahwa pada dasarnya semua tulisan dapat dikelompokkan ke dalam empat macam karangan, yaitu: a) narasi (cerita), b) eksposisi (paparan), c) deskripsi (lukisan), dan d) argumentasi.

Dapat disimpulkan bahwa keterampilan menulis merupakan keterampilan yang tidak hanya memerlukan keahlian dalam menulis aksara tetapi juga memerlukan keahlian dalam memberikan ide, pikiran, gagasan dan perasaan yang dituangkan dalam tulisan. Tata bahasa dan penggunaan kata yang tepat juga dibutuhkan agar para pembaca dapat mengerti dan ikut merasakan apa yang ditulis oleh pengarang.

\section{Pengajaran Keterampilan Menulis Untuk Dewasa}

Dalam pengajaran keterampilan menulis [6] mengatakan pengajar harus dapat menganalisis proses pembelajaran di kelas dan memeriksa latihan secara terperinci, pengajar tidak hanya memperhatikan gaya bahasa dan kesesuaian penulisan, tetapi juga memperhatikan unsur komunikatif dan konten isi dalam menyampaikan pesan yang terdapat didalam penulisan.

Dalam latihan menulis, pembelajar sering sekali melakukan kesalahan seperti putih (白 bai) menjadi ratusan (百 bai) sehingga dapat mempengaruhi makna. Oleh karena itu, meskipun penulisan aksara bukan bagian terpenting dalam pengajaran tertulis, tapi ada beberapa materi ajar tingkat dasar yang khusus membahas tentang penulisan aksara, jika dalam penulisan sebuah karangan ada aksara yang salah maka pengajar harus sering menggantinya dengan aksara yang benar.

Pengajaran keterampilan menulis untuk dewasa pada pembelajaran bahasa Mandarin, bukan hanya sekedar menulis aksara, mengenal radikal dan urutan guratan, tetapi membuat kalimat dan mengarang. Setiap membuat karangan pembelajar terkadang merasa kesulitan dalam menuangkan ide pikirannya, terlebih lagi menggunakan bahasa asing yaitu bahasa Mandarin. Selanjutnya pembelajar akan berfikir keras untuk memperhatikan tata bahasa juga penggunaan bahasa yang tepat.

\section{Penelitian terdahulu}

Penelitian mengenai metode pembelajaran Ziran sampai saat ini belum ada yang menggembangkan. Seperti yang sudah dijelaskan sebelumnya metode pembelajaran Ziran merupakan kolaborasi dari metode quantum teaching dan tutor teman sebaya, untuk kedua metode tersebut tentunya sudah ada penelitian yang telah dilakukan sehingga hasil dari penerapan kedua metode tersebut telah terbukti keberhasillannya. Berikut beberapa penelitian terdahulu yang berkaitan dengan metode quantum teaching dan tutor teman sebaya:

1. Model Materi Ajar Berbicara Bahasa Mandarin Berbasis Pendekatan Kuantum oleh Tri Budianingsih publish pada Journal of 
Education, Teaching and Learning Volume 3 Number 1 March 2018. Page 159-165 p-ISSN: 2477-5924 e-ISSN: 2477-8478. Artikel ini membahas tentang pengembangan materi ajar berbicara bahasa Mandarin yang memiliki pendekatan khusus yaitu pendektan kuantum. Penelitian dilakukan di salah satu universitas swasta di Jakarta semester 2 (dua). Hasil yang didapat pada penelitian ini adalah mahasiswa setelah menggunakan materi ajar tersebut memiliki peningkatan secara baik dilihat dari hasil belajar pretest dan posttest, lebih percaya diri, lebih senang mengikuti perkuliahan, sosialisasi dan interaksi yang baik diantara siswa dan pengajar.

2. Penerapan Model Tutor Sebaya pada Mata Pelajaran Bahasa Inggris Reported Speech terhadap Hasil Belajar Peserta didik MAN Kota Probolinggo oleh Niken Sholi Indrianie publish pada Jurnal Kebijakan dan Pengembangan Pendidikan Volume 1, Nomor 1, Januari 2015; 126-132 ISSN: 2337-7623; EISSN: 2337-7615. Artikel ini membahas tentang hasil belajar peserta didik pada mata pelajaran bahasa Inggris Reported Speech dengan menggunakan pembelajaran cooperative learning model tutor sebaya. Penelitian ini dilaksanakan di MAN Kota Probolinggo dengan pendekatan kuantitatif. Hasil penelitian menunjukkan bahwa pembelajaran cooperative learning model tutor sebaya terlaksana dengan baik sesuai dengan sintak pembelajaran yang direncanakan. Aktivitas peserta didik yang berperan sebagai tutor dapat melaksanakan fungsinya dengan baik. Kemampuan peserta didik sebagai tutor dalam membimbing temannya untuk memahami dan memecahkan masalah bahasa Inggris Reported Speech dapat berjalan dengan baik dan pada langkah penyelesaian serta langkah mengerjakan soal evaluasi dapat terlaksana dengan baik serta menunjukkan hasil belajar yang cukup meningkat.

\section{METODE}

\section{Data Penelitian}

Pada penelitian ini, data diambil dari kusioner tentang analisis kebutuhan dan karakteristik mahasiswa keterampilan bahasa tertulis lanjutan A\&B. Kegiatan tersebut merupakan bagian dari perkuliahan "Keterampilan Bahasa Tertulis Lanjutan" yang merupakan mata kuliah wajib bagi mahasiswa tingkat dua. Sebanyak 30 mahasiswa, yang terdiri dari 5 mahasiswa laki-laki dan 25 mahasiswa perempuan, seluruh mahasiswa yang menjadi subjek penelitian ini bukan merupakan suku Tionghoa, mereka yang akan mengisi kusioner analisis kebutuhan dan karakteristik mahasiswa juga satu orang dosen pengampuh.

\section{Analisis Data}

Tabel 1 Analisis data pada penelitian.

\begin{tabular}{lll}
\hline Data & $\begin{array}{l}\text { Instrumen } \\
\text { Pengumpulan } \\
\text { Data }\end{array}$ & $\begin{array}{l}\text { Teknik } \\
\text { Analisis } \\
\text { Data }\end{array}$ \\
\hline $\begin{array}{l}\text { Analisis } \\
\begin{array}{l}\text { Kebutuhan } \\
\text { Analisis } \\
\text { Karakteristik }\end{array}\end{array}$ & Kusioner & Nilai Skor \\
Kuesioner & $\begin{array}{l}\text { Rata-rata } \\
\text { (Mean) }\end{array}$ \\
\hline
\end{tabular}

Data yang diambil dari analisis kebutuhan dan karakteristik mahasiswa dan dosen adalah kusioner, peneliti akan menyiapkan kisi-kisi kusioner yang terdapat dimensi dan indikator penilaian. Kategori kusioner analisis kebutuhan ada tiga yaitu tidak memadai, kurang memadai, dan memadai. Setelah dikategorikan secara keseluruhan akan dijelaskan secara terperinci (deskriptif). Berikut rumus penilaian skor analisis kebutuhan;

Nilai Skor $=\frac{\{(\operatorname{skor} 1 \times 1)+(\operatorname{skor} 2 \times 2)+(\operatorname{skor} 3 \times 3)+(\operatorname{skor} 4 \times 4)\}}{\left\{\left(\sum \text { skor } 1\right)+\left(\sum \text { skor } 2\right)+\left(\sum \text { skor } 3\right)+\left(\sum \text { skor } 4\right)\right\}}$

Kusioner analisis kebutuhan menggunakan gabungan skala likert dan skala guttman. Skala likert variabel yang akan diukur dijabarkan menjadi indikator variabel, jawaban setiap item instrumen yang menggunakan skala likert mempunyai gradasi dari sangat positif sampai sangat negatif, yang dapat berupa kata-kata, untuk keperluan analisis kuantitatif maka jawaban dapat diberi skor. Sedangkan skala guttman akan didapat jawaban yang tegas, yaitu "ya-tidak"; "benar-salah"; "pernah-tidak pernah"; "positif-negatif" dan lainlain. Tabel 2 meruapakan kategori analisis kebutuhan.

Tabel 2 Kategori Analisis Kebutuhan

\begin{tabular}{|c|c|c|}
\hline $\begin{array}{l}\text { Presentasi } \\
\text { Rata-rata } \\
\text { Kriteria } \\
\text { Kebutuhan }\end{array}$ & Kategori & Keterangan \\
\hline $0-2.5$ & $\begin{array}{l}\text { Tidak } \\
\text { Memadai }\end{array}$ & $\begin{array}{l}\text { Tidak menjadi } \\
\text { perioritas }\end{array}$ \\
\hline $2.6-2.9$ & $\begin{array}{l}\text { Cukup } \\
\text { Memadai }\end{array}$ & $\begin{array}{l}\text { Tidak menjadi } \\
\text { perioritas }\end{array}$ \\
\hline
\end{tabular}




\begin{tabular}{lll}
\hline $\begin{array}{l}\text { Presentasi } \\
\text { Rata-rata } \\
\text { Kriteria } \\
\text { Kebutuhan }\end{array}$ & Kategori & Keterangan \\
\hline $3.0-4.0$ & Memadai & $\begin{array}{l}\text { Menjadi } \\
\text { perioritas }\end{array}$ \\
\hline
\end{tabular}

Kuesioner kedua adalah analisis karakteristik, Kusioner analilsis karakteristik ini menggunakan gabungan skala guttman dan pertanyaan terbuka, kuesioner tersebut memiliki pilihan jawaban yang beraneka ragam yaitu ya dan tidak, dan jawaban a, b, c, dan e. Selain itu juga peneliti juga akan merumuskan gaya belajar mahasiswa dengan data yang diperoleh langsung dibuat rekapitulasinya berdasarkan gaya belajar. Berikut cara menganalisis data tersebut:

1. Terdapat 4 kelompok pertanyaan yang mencirikan gaya belajar mahasiswa, yaitu "V" (Visual), "A" (Audiovisual), "A" (Auditorial), dan "K" (Kinestetik). Setiap pertanyaan memiliki pilihan jawaban: "sering" skor 3, "kadang-kadang" skor 2, "tidak sering" skor 1.

2. Setelah masing-masing kelompok dijumlahkan akan terlihat hasil dari pertanyaan gaya balajar tersebut.

3. Penarikan kesimpulan akan membandingkan empat nilai masing-masing kelompok pertanyaan Berikut kesimpulan penarikan berdasarkan: a) Nilai tertinggi pada satu kelompok pertanyaan, maka cenderung dominan pada gaya berlajar tersebut; b) Dua nilai tertinggi yang sama dari dua kelompok atau nilainya hanya selisih 1-2 poin dari dua nilai tertinggi, maka tergolong dalam "Gabungan kedua Gaya Belajar" tersebut.

4. Setelah penarikan kesimpulan dibuat rekapitulasi presentase kecenderungan gaya belajar pada mahasiswa prodi Tiongkok tingkat 2.

Tabel 3 adalah kategori analisis karakteristik.

Tabel 3 Kategori Analisis Karakteristik

\begin{tabular}{lll}
\hline $\begin{array}{l}\text { Presentasi } \\
\text { Rata-rata } \\
\text { Kriteria } \\
\begin{array}{l}\text { Karakteristik } \\
(\%)\end{array}\end{array}$ & Kategori & Keterangan \\
\hline $0-25$ & $\begin{array}{l}\text { Tidak } \\
\text { diperhatikan }\end{array}$ & $\begin{array}{l}\text { Tidak } \\
\text { menjadi } \\
\text { perhatian } \\
\text { Tidak } \\
\text { menjadi } \\
\text { perhatian }\end{array}$ \\
\hline
\end{tabular}

\begin{tabular}{|c|c|c|}
\hline $\begin{array}{l}\text { Presentasi } \\
\text { Rata-rata } \\
\text { Kriteria } \\
\text { Karakteristik } \\
(\%)\end{array}$ & Kategori & Keterangan \\
\hline $51-75$ & Diperhatikan & $\begin{array}{l}\text { Menjadi } \\
\text { perhatian }\end{array}$ \\
\hline $76-100$ & $\begin{array}{l}\text { Sangat } \\
\text { diperhatikan }\end{array}$ & $\begin{array}{l}\text { Menjadi } \\
\text { perhatian }\end{array}$ \\
\hline
\end{tabular}

\section{HASIL DAN PEMBAHASAN}

\section{Hasil Analisis Kebutuhan Dosen}

Berdasarkan pelaksanaan Survei Kebutuhan Terhadap RPS Pembelajaran Ziran Berbasis Pendekatan Tutor Teman Sebaya dengan menggunakan metode Kuesioner, untuk kemudian Kuesioner tersebut kami sebar kepada sampling yang terdiri dari 2 orang Dosen dan 30 orang Mahasiswa/i.

Adapun Komponen penilaian pada pelaksanaan Survei Kebutuhan Terhadap RPS Pembelajaran Ziran Berbasis Pendekatan Tutor Teman Sebaya dikelompokkan menjadi 9 (sembilan) komponen utama sebagai berikut :

1. Instrumen Identifikasi Kebutuhan.

2. Kebutuhan Terhadap Tujuan Pembelajaran Ziran Berbasis Pendekatan Tutor Teman Sebaya..

3. Kebutuhan Terhadap Tema Pembelajaran Ziran Berbasis Pendekatan Tutor Teman Sebaya.

4. Kebutuhan Terhadap Pendekatan Pembelajaran.

5. Kebutuhan Terhadap Pembelajaran Ziran.

6. Kriteria Kebutuhan Kegiatan Awal.

7. Kriteria Kebutuhan Kegiatan Inti.

8. Kriteria Kebutuhan Kegiatan Refreksi.

9. Kriteria Kebutuhan Kegiatan Penutup.

Kuesioner yang dibagikan terdiri dari 73 (tujuh puluh tiga) pertanyaan yang bertujuan untuk memotret Survei Kebutuhan Terhadap RPS Pembelajaran Ziran Berbasis Pendekatan Tutor Teman Sebaya, sehingga diharapkan responden dapat mengisi secara obyektif. Kuesioner akan menggali informasi mengenai Kebutuhan Terhadap RPS Pembelajaran Ziran Berbasis Pendekatan Tutor Teman Sebaya. Responden diharapkan mengisi kuesioner dengan benar sesuai dengan kondisi yang ada.

Setiap pertanyaan memiliki nilai 1 (satu) sampai dengan 4 (empat), dengan penjelasan sebagai berikut: 
1. Skor 1 menggambarkan sangat tidak setuju/ tidak pernah.

2. Skor 2 menggambarkan tidak setuju, tidak/jarang.

3. Skor 3 menggambarkan setuju/ya/biasa.

4. Skor 4 menggambarkan sangat setuju/sering.

Berikut Hasil Survei Kebutuhan Terhadap RPS Pembelajaran Ziran Berbasis Pendekatan Tutor Teman Sebaya:

\section{Instrumen Identifikasi Kebutuhan}

Pada bagian ini kita dapat melihat kebutuhan apa saja yang dibutuhkan oleh dosen dan mahasiswa dalam pengembangan kolaborasi metode pembelajaran bahasa, Gambar 1 merupakan hasil instrument identifikasi kebutuhan.

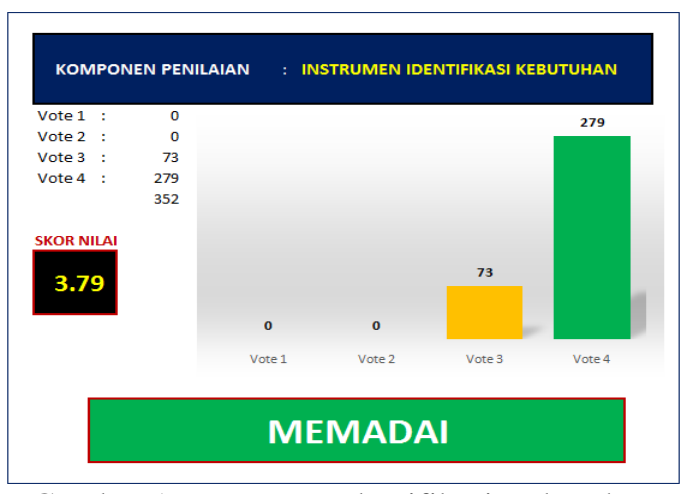

Gambar 1. Instrumen Identifikasi Kebutuhan

Total skor pada poin ini 3,79 karena lebih dari pencapaian yang diharapkan. Pada poin ini yang dibutuhkan adalah materi, kegiatan pembelajaran Ziran berbasis pendekatan tutor teman sebaya dan quantum teaching, Tujuan pembelajaran dan Evaluasi karena aspek tersebut memiliki nilai tertinggi yaitu 4,00 dengan kesimpulan Memadai.

\section{Kebutuhan Terhadap Tujuan Pembelajaran Ziran Berbasis Pendekatan Tutor Teman Sebaya.} Setelah mengetahui kebutuhan dosen dan mahasiswa, langkah selanjutnya adalah menentukan tujuan dari pengembangan kolaborasi metode pembelajaran bahasa tersebut, Gambar 2 merupakan hasil instrument.

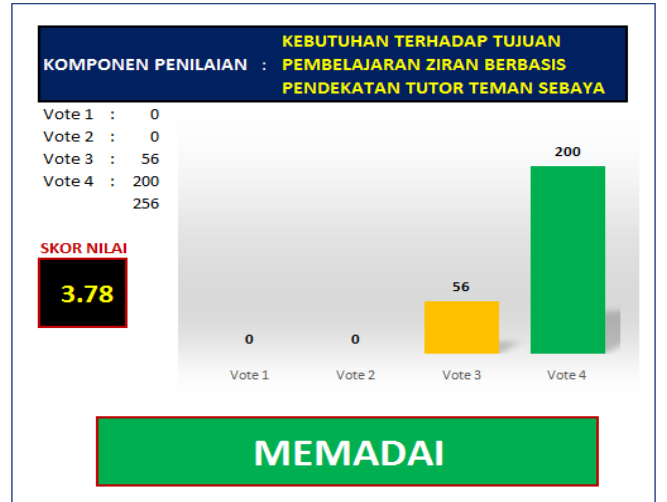

Gambar 2. Kebutuhan Terhadap Tujuan Pembelajaran Ziran Berbasis Pendekatan Tutor Teman Sebaya.

Total skor pada poin ini 3,78 karena lebih dari pencapaian yang diharapkan. Pada poin ini yang dibutuhkan adalah memahami pertanyaan yang terdapat dalam teks, memahami tata bahasa, dan kegiatan pembelajaran Ziran berbasis tutor teman sebaya dan quantum teaching karena aspek tersebut memiliki nilai tertinggi yaitu 4,00 dengan kesimpulan Memadai

\section{Kebutuhan Terhadap Tema Pembelajaran Ziran Berbasis Pendekatan Tutor Teman Sebaya}

Selain itu juga tema dalam pengembangan kolaborasi metode pembelajaran bahasa ini juga diperlukan agar semuanya sesuai dengan tujuan dan kebutuhan dosen dan mahasiswa, Gambar 3 merupakan hasil instrumentnya.

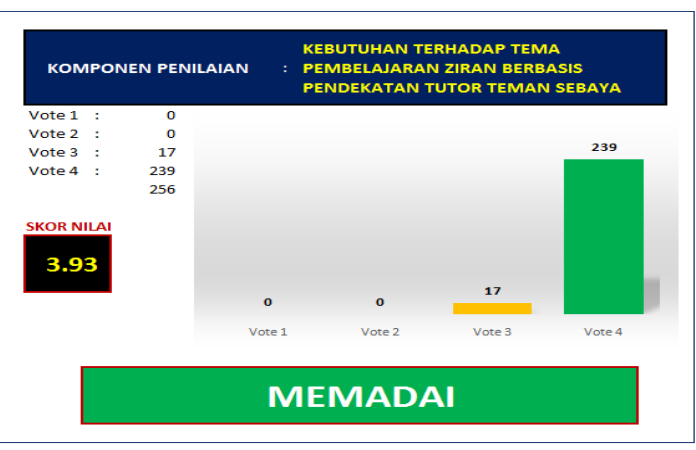

Gambar 3. Kebutuhan Terhadap Tema Pembelajaran Ziran Berbasis Pendekatan Tutor Teman Sebaya

Total skor pada poin ini 3,93 karena lebih dari pencapaian yang diharapkan. Pada poin ini yang dibutuhkan adalah tema makanan khas Tiongkok, tema perayaan/festival, materi dan uraian materi karena aspek tersebut memiliki nilai tertinggi yaitu 4.00 dengan kesimpulan Memadai 


\section{Kebutuhan \\ Terhadap \\ Pendekatan Pembelajaran}

Selanjutnya adalah kebutuhan yang lebih khusus dalam instrument pengembangan ini adalah pada pendekatan pembelajaran tersebut, agar lebih spesifik dalam menentukan langkah selanjutnya, Gambar 4 merupakan hasil instrumen kebutuhan terhadap pendekatan pembelajaran.

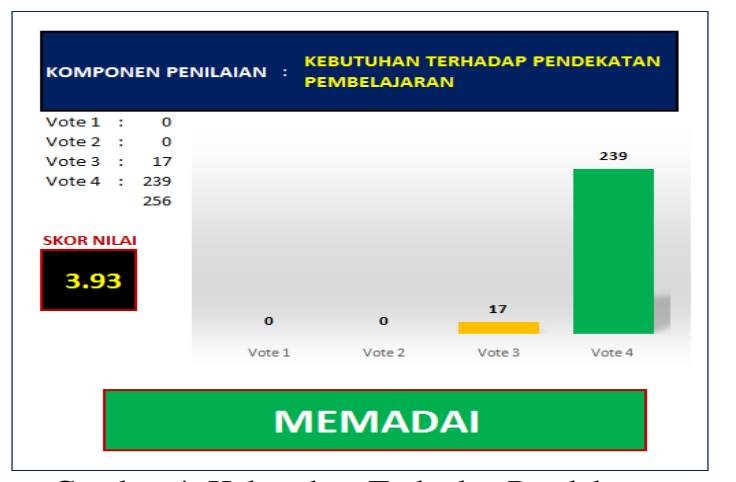

Gambar 4. Kebutuhan Terhadap Pendekatan Pembelajaran

Total skor pada poin ini 3,93 karena lebih dari pencapaian yang diharapkan. Pada poin ini yang dibutuhkan adalah proses pembelajaran tutor teman sebaya, proses pembelajaran kelompok, proses pembelajaran inquiri, proses pembelajaran masyarakat belajar dan kegiatan pembelajaran karena aspek tersebut memiliki nilai tertinggi yaitu 4.00 dengan kesimpulan memadai

\section{Kebutuhan Terhadap Pembelajaran Ziran}

Inti dari pengembangan ini adalah dalam pengembangan kolaborasi metode pembelajaran bahasa yang diberi nama oleh penulis adalah Ziran, kolaborasi pengembangan metode ini menggabungkan dua metode pembelajaran quantum teaching dan tutor teman sebaya, Gambar 5 merupakan hasil instrumen kebutuhan terhadap pembelajaran ziran.

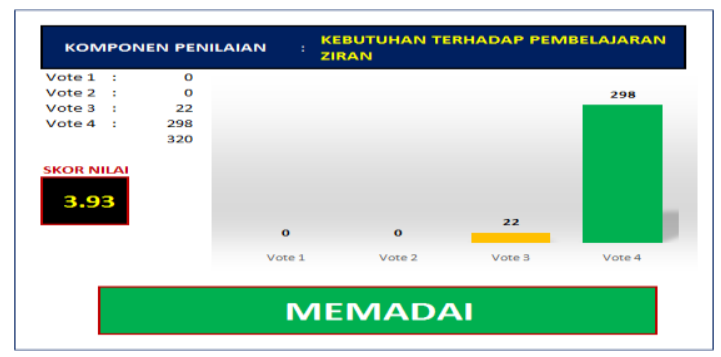

Gambar 5. Kebutuhan Terhadap Pembelajaran Ziran

Total skor pada poin ini 3,93 karena lebih dari pencapaian yang diharapkan. Pada poin ini yang dibutuhkan adalah uraian dan penjelasan materi, dibutuhkan pembagian kelompok, dibutuhkan diskusi kelompok dan dibutuhkan sesi tanya jawab karena aspek tersebut memiliki nilai tertinggi yaitu 4.00 dengan kesimpulan Memadai.

\section{Kriteria Kebutuhan Kegiatan Awal}

Selanjutnya adalah kebutuhan kegiatan awal dalam pengembangan kolaborasi metode pengajaran bahasa, pada bagian ini penulis ingin mengetahui pada awal perkuliahan langkah pertama apa yang dilakukan agar pengkolaborasi dua metode pengembangan ini sesuai kebutuhan dosen dan mahasiswa, Gambar 6 merupakan hasil instrumen kriteria kebutuhan kegiatan awal.

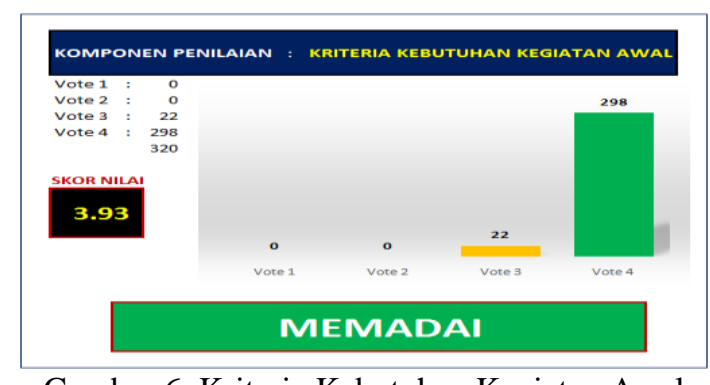

Gambar 6. Kriteria Kebutuhan Kegiatan Awal

Total skor pada poin ini 3,93 karena lebih dari pencapaian yang diharapkan. Pada poin ini yang dibutuhkan adalah penjelasan kompetensi, menjelaskan mengenai indikator, proses kegiatan dan mempresentasikan setiap kelompok karena aspek tersebut memiliki nilai tertinggi yaitu 4.00 dengan kesimpulan Memadai.

\section{Kriteria Kebutuhan Kegiatan Inti}

Kemudian adalah pada kegiatan inti dalam pembelajaran dalam kolaborasi pengembangan dua metode pembelajaran bahasa, Gambar 7 merupakan hasil instrumen kriteria kebutuhan kegiatan inti.

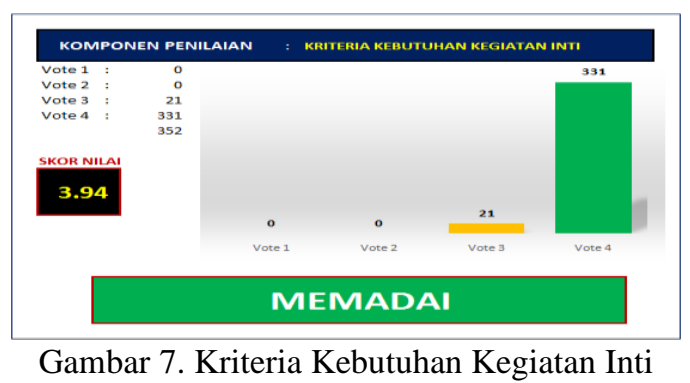

Total skor pada poin ini 3,94 karena lebih dari pencapaian yang diharapkan. Pada poin ini yang dibutuhkan adalah diskusi kelompok, mampu memberi makna, mampu menemukan sesuatu dan mampu bertanya karena aspek tersebut memiliki nilai tertinggi yaitu 4,00 dengan kesimpulan Memadai. 


\section{Kriteria Kebutuhan Kegiatan Refreksi}

Sebelum pembelajran berakhir dosen mengadakan kegiatan refkresi kepada mahasiswa untuk mengetahui sejauh mana mahasiswa memahami pelajaran tersebut, Gambar 8 merupakan hasil instrumen kriteria kebutuhan kegiatan refreksi.

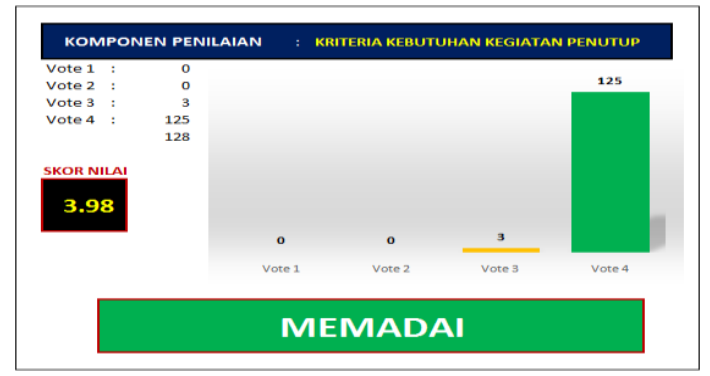

Gambar 8. Kriteria Kebutuhan Kegiatan Refreksi

Total skor pada poin ini 3,98 karena lebih dari pencapaian yang diharapkan. Pada poin ini yang dibutuhkan adalah kesan dan saran mahasiswa, dan hasil karya mahasiswa karena aspek tersebut memiliki nilai tertinggi yaitu 4,00 dengan kesimpulan Memadai.

\section{Kriteria Kebutuhan Kegiatan Penutup}

Terakhir pada analisis kebutuhan ini adalah pada bagian penutup pembelajaran, pada bagian ini dosen melakukan kegiatan penutup pembelajaran dengan melihat cara dosen dalam menyimpulkan pembelajaran pada hari tersebut, Gambar 9 merupakan hasil instrumen kriteria kebutuhan kegiatan penutup.

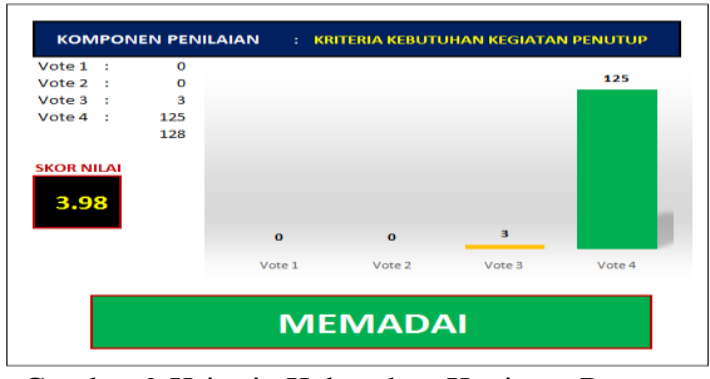

Gambar 9 Kriteria Kebutuhan Kegiatan Penutup

Total skor pada poin ini 3,98 karena lebih dari pencapaian yang diharapkan. Pada poin ini yang dibutuhkan adalah lembar pengumpulan data, dan menyimpulkan pembelajaran hari ini karena aspek tersebut memiliki nilai tertinggi yaitu 4,00 dengan kesimpulan Memadai. Sehingga secara total pencapaian adalah 3,89 .

\section{Hasil Analisis Karakteristik Mahasiswa}

Berdasarkan hasil kuesioner yang telah disebarkan kepada mahasiswa dapat disimpulkan sebagai berikut, dilihat dari latar belakang mahasiswa dalam mempelajari bahasa Mandarin ada 89\% mahasiswa bukan keluarga keturunan Tionghoa, $11 \%$ merupakan keturunan Tionghoa dan 95\% orang tua mahasiswa tidak bisa berbahasa Mandarin, sehingga mereka hanya dapat berbicara bahasa Mandarin dan mengenal bahasa Mandarin dalam lingkungan kampus, teman dan dosen-dosennya, dan ada sebanyak $5 \%$ orang tua mahasiswa bisa berbahasa Mandarin. Walaupun sebagian besar mahasiswa tidak memiliki latar belakang bahasa Mandarin yang cukup, tetapi motivasi dan keinginan mereka untuk bisa berbahasa Mandarin dengan baik sangat besar, hal ini dapat dilihat ada sebanyak $75 \%$ mahasiswa masuk prodi Tiongkok karena keinginan sendiri dan $25 \%$ dikarenakan keinginan orang tua.

Dalam pengalaman belajar berbahasa Mandarin ada sebanyak 79\% mahasiswa tidak lebih dari satu tahun telah mempelajari bahasa Mandarin, mereka mulai belajar Mandarin saat di bangku kuliah, dan sisanya $21 \%$ mahasiswa pernah belajar saat tingkat SMA. Sebanyak $79 \%$ juga mahasiswa saat di luar jam kuliah tidak terlalu sering berbicara bahasa Mandarin dengan teman sekelasnya dikarenakan beberapa alasan, salah satunya adalah kurangnya kosakata mereka sehingga membuat mereka kurang percaya diri dalam berbicara bahasa Mandarin dan takut salah, dan $21 \%$ mahasiswa sering berbicara bahasa Mandarin dengan teman sekelas, sedangkan ada sebanyak $84 \%$ mahasiswa saat di luar jam kuliah juga tidak terlalu sering berbicara bahasa Mandarin dengan dosennya dengan alasan yang sama, dan $16 \%$ mahasiswa sering berbicara bahasa Mandarin dengan dosen di luar jam kuliah. Mahasiswa dalam hal ini sangat menyadari bahwa bahasa Mandarin merupakan salah satu bahasa asing yang sulit untuk dipelajari, ada sebanyak $89 \%$ mahasiswa berpendapat demikian, dan $11 \%$ mahasiswa tidak berpendapat demikian. Menurut 20\% mahasiswa berpendapat aksara baru merupakan yang paling sulit dipelajari karena bahasa Mandarin tidak memiliki abjad semua perkata, $15 \%$ mahasiswa berpendapat urutan guratan juga sulit untuk dipelajari karena beda guratan dan kurang satu guratan dapat berbeda makna kalimatnya dan penulisan nada pun dapat mempengaruhinya. Tingkat kesulitan terakhir menurut mahasiswa adalah tata bahasa, sebanyak 52\% mahasiswa berpendapat tata bahasa sulit untuk dipelajari karena bahasa Mandarin memiliki tata bahasa yang berbeda dengan bahasa Indonesia yaitu M-D bukan D-M, dan $13 \%$ mahasiswa berpendapat memahami kalimat dan memahami pertanyaan terdapat dalam teks juga merupakan bagian sulit dalam mempelajari 
bahasa Mandarin. Untuk mengatasi kendala tersebut ada sebanyak $79 \%$ mahasiswa cara mengatasinya adalah bertanya dengan dosen baik dalam jam mata kuliah ataupun di luar jam kuliah, dan 21\% mahasiswa bertanya kepada temannya.

Bagian terakhir dalam analisis karakteristik adalah gaya belajar, dalam gaya belajar ada sebanyak $52 \%$ mahasiswa lebih suka dan tertarik belajar sambil melihat TV atau Video, menurut mereka dengan belajar sambil melihat TV/Video atau belajar dengan melihat TV/Video lebih mudah membuat mereka untuk menghafal lebih cepat, dan tidak membosankan, ada $20 \%$ mahasiswa juga suka belajar berkelompok dengan teman sebayanya, menurut mereka belajar kelompok juga dapat memudahkan mereka dalam menerima materi ataupun bertanya pada teman jika materi tersebut sulit untuk dipahami, selain belajar kelompok 15\% mahasiswa juga suka belajar sendiri dengan suasana yang sunyi sehingga dapat memudahkan mereka dalam menerima pelajaran, dan $13 \%$ mahasiswa lebih suka belajar dengan sambil mendengarkan musik/rekaman.

Pada hasil penelitian yang telah dijabarkan sebelumnya sangat jelas terlihat bahwa dosen dan mahasiswa sangat membutuhkan kegiatan refleksi dan kegiatan penutup dengan presentasi total pencapaian 3,98; kegiatan tersebut mereka sangat berharap dapat lebih memahami materi yang diberikan dan mendapatkan sesuatu yang berharga, tidak ingin setiap pertemuan berakhir begitu saja tetapi ada tindak lanjut seperti menyimpulkan hasil diskusi, mengutarakan apa yang diperoleh pelajaran hari ini, hasil karya mereka, bahkan memberikan kesempatan kepada mahasiswa untuk memberikan kesan dan saran pada setiap pertemuan perkuliahan. Kebutuhan selanjutnya adalah pada kegiatan inti dengan presentasi total pencapaian 3,94 pada kegiatan ini mahasiswa melakukan kegiatan pembelajaran yang menyenangkan karena pada kegiatan inti langkah-langkah baik dari kedua metode digabungkan menjadi satu seperti pada bagian diskusi kelompok, langkah tersebut merupakan salah satu dari metode tutor teman sebaya dimana satu mahasiswa yang menjadi tutor akan mengajarkan temannya di dalam kelompoknya sehingga terjadilah diskusi kelompok. Salah satu langkah dari metode quantum teaching adalah mampu bertanya, seperti yang sudah diutrakan pada teori Bobby De Potter bahwa tujuan utama metodenya adalah semua berbicara, sehingga pada langkah tersebut mahasiswa diharapkan harus percaya diri untuk berbicara.
Presentasi dengan total pencapaian 3,93 yaitu tema, pendekatan, pembelajaran dan kegiatan awal yang dibutuhkan dosen dan mahasiwa. Pada kegiatan ini mereka memilih kebutuhan yang sesuai dengan mereka seperti pada bagian tema ada 4 yang memilih tema makanan khas Tiongkok, dan tema perayaan festival. Tema tentang budaya sangat cocok untuk mahasiswa dengan begitu mereka akan lebih mudah mempelajari bahasa Mandarin melalui budaya Tiongkok. Kemudian kegiatan pembelajaran Ziran berbasis pendekatan tutor teman sebaya juga merupakan pencapaian yang tinggi dipilih oleh mahasiswa dan dosen yaitu dengan presentasi 4 , mereka sangat antusias dengan metode tersebut begitu juga dengan pada kegiatan pendekatan memilih pembelajaran Ziran berbasis pendekatan tutor teman sebaya. Pada kegiatan pembelajaran Ziran dosen dan mahasiswa sangat antusias dengan kebutuhan uraian atau penjelasan materi dijelaskan secara terperinci, pembagian kelompok secara random, diskusi kelompok dan membutuhkan sesi tanya jawab, semua kegiatan tersebut mendapatkan presentasu tertinggi yaitu 4 .

\section{KESIMPULAN}

Berdasarkan penelitian yang dilakukan pada keterampilan tertulis bahasa Mandarin tingkat dua Universitas Al Azhar Indonesia, Jakarta dengan menganalisis kebutuhan dosen dan mahasiswa pada metode pembelajaran Ziran berbasis pendekatan tutor teman sebaya dapat ditarik kesimpulan sebagai berikut: 1) Total pencapaian dari analisis kebutuhan dari 9 komponen sebesar 3,89, lebih besar dari pencapaian yang diharapkan yaitu sebesar 3,00. 2) Total pencapaian tertinggi ada pada komponen kriteria kebutuhan kegiatan refreksi dan kriteria kebutuhan kegiatan penutup sebesar 3,98, pencapain kedua pada komponen kriteria kebutuhan kegiatan inti sebesar 3,94, pencapaian ketiga pada komponen kriteria tema, pendekatan, pembelajaran dan kegiatan awal sebesar 3,93 dan pencapaian terendah pada komponen kriteria identifikasi kebutuhan RPS sebesar 3,79 dan tujuan pembelajaran sebesar 3,78. Berdasarkan hasil penelitian di atas dapat disimpulkan dalam merancang sebuah metode baru analisis kebutuhan yang telah dilakukan peneliti dapat dijadikan rekomendasi atau dasar yang baik, dapat dilihat bahwa dosen dan mahasiswa sangat membutuhkan sebuah metode yang baru yaitu kolaborasi metode quantum teaching dengan tutor teman sebaya. 


\section{UCAPAN TERIMA KASIH}

Terima kasih kepada Lembaga Penelitrian dan Pengabdian Masyarakat (LP2M) Universitas Al Azhar Indonesia yang telah memberikan dukungan moril maupun materi kepada penulis, sehingga penulis dapat menyelesaikan penelitian ini.

\section{REFERENSI}

[1] I. A. Pratiwi, "Pengembangan Model Kolaborasi Jigsaw Role Playing Sebagai Upaya Peningkatan Kemampuan Bekerjasama Siswa Kelas V SD Pada Pelajaran IPS," Jurnal Konseling Gusjigang, p. Vol 1 No 2, 2015.

[2] N. S. Sukmadinata, Metode Penelitian Pendidikan, Bandung: PT. Remaja Rosdakarya, 2008.

[3] J. C. Richards, Curriculum Development in Language Teaching, Cambridge: Cambridge University Press, 2001.
[4] F. Sanubari, S. Yamtimah and T. Redjeki, "Penerapan Metode Pembelajaran Tutor Teman Sebaya Dilengkapi Dengan Media Interaktif Flash untuk Meningkatkan Minat dan Prestasi Belajar Siswa Kelas XI IPA 1 SMA Negeri 1 Sukoharjo Tahun Pelajaran 2013/2014 Pada Materi Larutan Penyangga," Jurnal Pendidikan Kimia Universitas Sebelas Maret, vol. 3, no. 4, 2014.

[5] R. Arjanggi and T. Suprihatin, "Metode Pembelajaran Tutor Teman Sebaya Meningkatkan Hasil Belajar Berdasarkan Regulasi-Diri," Makara (Human Behavior Studies in Asia), vol. 14, no. 2, 2010.

[6] W. Z. Wei, 汉语作为第二语言教学: 汉语技 能教学, Beijing: 外语教学与研究出版社, 2014.

[7] D. Z. d. Budiasih, Pendidikan Bahasa Indonesia 1, Jakarta: Depdiknas, 1997.

[8] S. Akhdiah, Pembinaan Kemampuan Menulis Bahasa Indonesia, Jakarta: Erlangga, 1988. 